\title{
In vivo investigation on the chronic hepatotoxicity induced by intraperitoneal administration of $10-\mathrm{nm}$ silicon dioxide nanoparticles
}

This article was published in the following Dove Press journal: International Journal of Nanomedicine

\author{
Mansour Almansour' \\ Saud Alarifi' \\ Bashir Jarrar ${ }^{2}$ \\ 'Department of Zoology, College \\ of Science, King Saud University, \\ Riyadh, Saudi Arabia; ${ }^{2}$ Department \\ of Biological Sciences, College of \\ Science, Jerash University, Jerash, \\ Jordan
}

Correspondence: Bashir M Jarrar Department of Biological Sciences, College of Science, Jerash University, PO Box 3II, Jerash 26I50, Jordan Mob +962 78646795 I

Fax +962 26350520

Email bashirjarrar@yahoo.com
Background: Silicon dioxide (silica) nanoparticles (SDNPs) are widely used in nanotechnology and medicine, but these nanomaterials may carry a high risk for human health while little is known about their toxicity.

Methods: We investigated the alterations in morphometry, biochemistry, hematology, histology of liver tissue and gene expression of drug-metabolizing enzymes induced by 10-nm SDNPs. Healthy male Wistar albino rats were exposed to 20, 35 and 50 repeated injections of SDNPs ( $2 \mathrm{mg} / \mathrm{kg}$ body weight). Whole blood, serum and plasma samples were used for hematological and biochemical analyses, whereas liver biopsies were processed for histopathological and gene expression alterations.

Results: In comparison with control rats, exposure to SDNPs lowered the body weight gain and liver index and increased the counts of white blood cells and platelets, but lowered the platelet larger cell ratio and plateletcrit. Levels of alkaline phosphatase, lactate dehydrogenase, lowdensity lipids, procalcitonin, aspartate aminotransferase and alanine aminotransferase, as well as potassium, phosphorus and iron concentrations, were increased. Histopathology revealed that SDNPs could induce hydropic degeneration, sinusoidal dilatation, hyperplasia of Kupffer cells, karyopyknosis and infiltration of inflammatory cells in the liver. SDNPs reduced the expression of 12 genes of drug-metabolizing enzymes significantly $(p<0.05)$.

Conclusion: These results suggest that SDNPs could cause alterations in morphometry, biochemistry, hematology, liver tissues and the expression of drug-metabolizing enzyme genes. Keywords: toxicity, histological alterations, morphometric alterations, hematological alterations, biochemical alterations, gene expression

\section{Introduction}

Silicon dioxide (silica) nanoparticles (SDNPs) are used in several areas due to their unique properties. ${ }^{1-5}$ SDNPs are easy to prepare and inexpensive to produce in hydrophobic and hydrophilic forms. Nanomaterials based on silica are photostable and have high porosity, large specific surface area, good functionalization and good biocompatibility. ${ }^{2,6}$ SDNPs are used in nanomedicine, especially in the delivery of drugs and genes, photodynamic therapy, molecular imaging, pharmaceutical additives and cancer therapy. ${ }^{7-11}$ In addition, SDNPs are used in several industries, including paints, pigment stabilization, lubricating oils, rubber antiaging, sensors, electronics, adhesive seals and functional textiles to protect materials from ultraviolet light and as bacteriocides. ${ }^{6,7}$ Large amounts of SDNPs are produced worldwide. ${ }^{5,12,13}$

Studies have shown that the toxicity of SDNPs is dependent upon their physicochemical properties (size, shape, surface moieties, charge and porosity) as well as their 
route of administration, dose, species and type of cell line employed. ${ }^{5}$ Despite many studies conducted on the toxicity of SDNP, long-term in vivo data are conflicting. ${ }^{5}$ Considerable data are available on the acute toxicity of these nanomaterials in vitro, but few signs of significant toxicity have been reported in chronically dosed animals.

Reports on the toxicity of nanomaterials have shown that SDNPs can induce alterations in gene expression due to their interaction with DNA, the cell cycle and the induction of oxidative stress. ${ }^{14,15}$ In addition, studies have reported that SDNPs can interact with immune cells, increase the production of reactive oxygen species (ROS), interleukin-1-beta and inflammatory mediators and increase phagocytosis with monocytes and macrophages. ${ }^{16}$ Other studies have revealed that SDNPs increased platelet aggregation and white blood cell (WBC) counts, reduced red blood cell (RBC) viability and aided the proliferation of $\mathrm{B}$ and $\mathrm{T}$ cells..$^{5,17,18}$ Moreover, studies have suggested that SDNPs facilitate conjunction with macromolecules and proteins and have an effect on adipocytes and the differentiation of cancer cells. ${ }^{3,4,19,20}$ Zhang et a ${ }^{15}$ showed that, in the human embryonic kidney cell line HEK293, the expression of 579 genes was upregulated and 1,263 genes was downregulated after $24 \mathrm{~h}$ of exposure to SDNPs (100 nm).

Toxicology studies have suggested that silica nanomaterials can accumulate and induce adverse effects in the liver, spleen, lungs and kidneys and could cross the blood-brain barrier. ${ }^{20}$ Moreover, SDNPs can induce systemic inflammation and macrophage activation in the lungs, liver and spleen. ${ }^{21}$ In vivo investigations have indicated that SDNPs can induce the following: vascular thrombosis, atherosclerosis, injury to Kupffer cells, pathological signs of Alzheimer's disease, injury to renal cells, pneumonia, testicular edema and spermatogenesis reduction. 5,15,22,23 In addition, Hassankhani et $\mathrm{al}^{24}$ suggested that silica nanomaterials can cause significant changes in the biochemical components of the plasma as well as toxic effects in the tissues of the liver, kidneys, lungs and testis. ${ }^{25-27}$ Other reports have demonstrated that SDNPs can induce the inflammatory response in lungs and lead to cell death. ${ }^{27-29}$ In addition, SDNPs are harmful to the immune response and toxic to macrophages, mammalian cell lines and mammalian tissues. ${ }^{19,30,31}$ Moreover, silica nanomaterials can induce oxidative stress and disturb the ratio of nitric oxide species and RBC lysis. ${ }^{32,33}$

The widespread use of SDNPs and rapid commercialization of these nanomaterials are worrying considering the toxicology concerns mentioned earlier. In this study, we sought to discover the morphometric, biochemical, hematological, hepatohistological and gene expression alterations that might be induced by the use of SDNPs.

\section{Materials and methods}

\section{Animals}

Adult healthy male Wistar albino rats $(\mathrm{n}=32 ; 205-235 \mathrm{~g})$ were investigated in the current study. Animals were maintained in stainless steel mesh cages with free access to tap water and pellets. In the housing room, the rats were maintained at a mean temperature of $21^{\circ} \mathrm{C} \pm 2^{\circ} \mathrm{C}$ and a mean relative humidity of $35 \%$.

\section{Nanoparticles (NPs)}

Spherical and porous silica powder (purity=99.5\%) with a surface area of $640 \mathrm{~m}^{2} / \mathrm{g}$ was obtained from Sigma-Aldrich Co. (St Louis, MO, USA). A fresh dispersion of NPs was disaggregated by ultrasonication after dilution with sterile physiological $(0.9 \% \mathrm{NaCl})$ saline at $37^{\circ} \mathrm{C}$ immediately before use. A solution of ultrasonicated NPs was prepared so that the dose could be administered at $1 \mathrm{~mL}$ via the intraperitoneal route. Four groups of eight rats were created as follows.

\section{Group I (control group)}

Each rat received physiological saline ( $1 \mathrm{~mL}$, i.p.) once daily for 5 days in 1 week; overall, these rats received 20, 35 or 50 injections.

\section{Group 2}

Each rat received SDNPs ( $2 \mathrm{mg} / \mathrm{kg}$ body weight) once daily for 5 days in 1 week; overall, these rats received 20 injections.

\section{Group 3}

Each rat received SDNPs $(2 \mathrm{mg} / \mathrm{kg}$ ) once daily for 5 days in 1 week; overall, these rats received 35 injections.

\section{Group 4}

Each rat received SDNPs $(2 \mathrm{mg} / \mathrm{kg}$ ) once daily for 5 days in 1 week; overall, these rats received 50 injections.

\section{Morphometric observation}

Rats in each group were observed every day throughout the study for general well-being, behavior patterns, food consumption, water intake and mortality. Moreover, all treated rats were observed during postdose periods for signs of toxicity. Body weight was monitored twice weekly as well as after 20, 35 and 50 injections of SDNPs.

\section{Percentage of absolute liver weight}

Rats were euthanized, and the liver was removed for immediate determination of the percentage of absolute liver weight. 


\section{Liver index}

The change in the liver index caused by SDNP exposure was determined using the following formula:

Mean weight of the liver/

Liver index $=\frac{\text { Mean weight of the experimental rats }}{\text { Weight of the control liver/ }}$

Weight of the control rats

\section{Biochemistry and hematology}

Rats were fasted overnight before blood collection as well as $24 \mathrm{~h}$ after SDNP exposure. Blood collection was carried out for all rats by heart puncture. Hematological tests were performed using a KX-21N analyzer (Sysmex, Kobe, Japan). An additional portion from each blood sample was centrifuged at 3,000 rpm for $5 \mathrm{~min}$ at room temperature for serum separation. Serum samples were assayed immediately to determine selected biochemical parameters using a BS-300 Auto Chemistry Analyzer (Golden Harvest Industries, Chennai, India).

\section{Histology}

Fresh small portions of the liver were taken from each rat. They were fixed in neutral buffered formalin, dehydrated in a series of increasing ethanol concentrations $(70 \%, 80 \%$, $90 \%, 95 \%$ and $100 \%$ ), cleared in chloroform, impregnated with paraffin wax, embedded and made into blocks. Paraffin sections $(4-5 \mu \mathrm{m})$ were stained with hematoxylin and eosin, periodic acid-Schiff, reticulin or Mallory trichrome. They were examined under light microscopy for histological alterations.

\section{Ribonucleic acid (RNA) extraction and analyses of gene expression}

Total RNA was isolated from liver tissues using TRI-

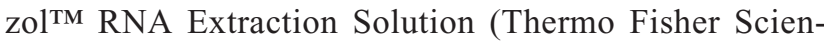
tific, Waltham, MA, USA) according to manufacturer's instructions. Then, $3 \mathrm{mg}$ of the isolated RNA was reverse transcribed at $42^{\circ} \mathrm{C}$ for $50 \mathrm{~min}$ in a reaction mixture containing 100 pmol oligo deoxythymidine, $2.5 \mathrm{mM}$ deoxyribonucleotide triphosphate, $0.1 \mathrm{M}$ dithiothreitol, first-strand buffer and 100 units of Murine leukemia virus reverse transcriptase for cDNA synthesis. Quantitative real-time polymerase chain reaction was performed using selective primers for cyp450 and ugt and were run on a CFX96 machine (Bio-Rad Laboratories Inc., Hercules, CA, USA). Polymerase chain reaction conditions were as follows: denaturation at $95^{\circ} \mathrm{C}$ for $10 \mathrm{~min}$ followed by 35 cycles of denaturation at $95^{\circ} \mathrm{C}$ for $30 \mathrm{~s}$ and annealing at $53^{\circ} \mathrm{C}$ for $30 \mathrm{~s}$. Relative mRNA expression was calculated using the $\Delta \mathrm{Ct}$ method (expression of the target gene was normalized to the expression of the housekeeping gene gapdh), as described previously. ${ }^{34}$ The results are presented as the fold change of mRNA gene expression of treated rats compared with control rats.

\section{Statistical analyses}

The independent Student's $t$-test and analysis of variance (ANOVA) were used for statistical analyses of results. The findings of morphometric, hematological, biochemical and gene expression analyses are expressed as the mean $\pm \mathrm{SD}$. $p<0.05$ was considered significant.

\section{Ethical approval of the study protocol}

Rats were treated according to the "guide for the care and use of experimental animals" (National Institutes of Health, Bethesda, MD, USA). All experiments were conducted according to the protocols approved by the animal care ethical committee of Jerash University (Jerash, Jordan).

\section{Results}

None of the rats in the experimental groups (groups 2, 3 and 4) died upon exposure to SDNPs. Rats in the control group (group 1) and experimental groups exhibited no signs of toxicity. Food consumption and water intake did not differ significantly between the control and experimental groups.

\section{Morphometric alterations}

Alterations in the body weight of rats subjected to SDNPs are presented in Tables 1 and 2 and Figure 1. Exposure to SDNPs affected body weight significantly $(p<0.05)$. There was a decrease in the mean body weight and percentage of weight gain in all groups exposed to SDNPs $(20,35$ or 50 injections) in comparison with control rats.

Table 3 summarizes a comparison of the mean weight of the liver and percentage of absolute liver weight of treated rats with control rats. The change in the liver index is presented in Figure 2 and Table 3. Overall, these data show that exposure to SDNPs induced lowering of the liver index and percentage of absolute liver weight.

\section{Biochemical alterations}

Exposure to SDNPs increased levels of aspartate aminotransferase (AST) and alanine aminotransferase (ALT) significantly $(p<0.001-0.05)$ in comparison with control rats (Table 4, Figure 3). Moreover, levels of ASL and ALT in rats 
Table I Biweekly body weight gain alterations induced in rats subjected to different injections of SDNPs in comparison with the rats received normal saline

\begin{tabular}{|c|c|c|c|c|c|c|c|c|c|}
\hline Group & & Week 0 & Week 2 & Week 4 & Week 6 & Week 8 & Week I0 & Week I 2 & Week I4 \\
\hline \multirow[t]{2}{*}{$\begin{array}{l}\text { Control rats } \\
\text { (normal saline) }\end{array}$} & $\begin{array}{l}\text { Average body } \\
\text { weight }(g)\end{array}$ & $230.8 \pm 25$ & $242.14 \pm 30$ & $257.25 \pm 21.5$ & $273.7 I \pm 3 I$ & $291 \pm 33$ & $307.95 \pm 24.6$ & $321.35 \pm 23$ & $335.45 \pm 17.58$ \\
\hline & $\begin{array}{l}\text { Amount of } \\
\text { change }(g)\end{array}$ & - & II. $34 \pm 2$ & $|5.1| \pm 2$ & $16.46 \pm 3$ & $17.1 \pm 2.3$ & $16.95 \pm 2$ & $13.4 \pm 1.7$ & $|4| \pm 2.4$. \\
\hline \multirow[t]{2}{*}{$\begin{array}{l}\text { Rats received } \mathrm{SiO}_{2} \\
\mathrm{NPs}(2 \mathrm{mg} / \mathrm{kg} \text { bw })\end{array}$} & $\begin{array}{l}\text { Average body } \\
\text { weight (g) }\end{array}$ & $2|0.31 \pm 3|$ & $223.45 \pm 24$ & $234.93 \pm 29.34$ & $245.45 \pm 31$ & $259.22 \pm 26$ & $270.12 \pm 18.55$ & $281.22 \pm 29$ & $292.47 \pm 22.93$ \\
\hline & $\begin{array}{l}\text { Amount of } \\
\text { change }(\mathrm{g})\end{array}$ & - & $13.14 \pm 2$ & II. $.48 \pm 2 *$ & $10.52 \pm I^{*}$ & $13.77 \pm 2 *$ & $10.9 \pm 2.6 *$ & $\mid I . I \pm 2.1$ & $11.25 \pm 1.6 *$ \\
\hline
\end{tabular}

Note: *A significant difference (Student's $t$-test, $p$-value of $<0.05$ ) in comparison with the body weight gain of control rats.

Abbreviations: NPs, nanoparticles; bw, body weight; SDNPs, silicon dioxide nanoparticles.

exposed to 20 or 35 injections were affected less significantly $(p<0.05)$ in comparison with rats exposed to 50 injections of SDNPs. In addition, rats exposed to SDNPs showed a significant increase $(p<0.05)$ in levels of creatine kinase and lactate dehydrogenase (LDH) which was dependent on the number of injections. SDNPs did not induce a significant alteration $(p>0.05)$ of serum electrolytes irrespective of the number of injections.

\section{Hematological alterations}

Control rats demonstrated normal range values with no hematological alterations of any of the parameters selected (Table 5, Figure 4). Exposure to SDNPs increased the WBC and platelet counts. SDNP-treated rats showed a significant $(p<0.05)$ decrease in the platelet larger cell ratio (P-LCR) and plateletcrit (PCT) value.

\section{Histological alterations in the liver}

Control rats exhibited normal hepatic structures, including lobule architecture, components of the portal hepatic space and hepatocytes (Figure 5A and B). Five main histological abnormalities were seen in the hepatic tissues of rats exposed to SDNPs, as described in the following subsections.

\section{Hydropic degeneration of hepatocytes}

Hepatocytes in experimental group rats demonstrated hydropic degeneration as well as swelling and cytoplasmic vacuolization (Figure 5C). This alteration was more prominent in the liver of rats exposed to 50 injections of SDNPs than those who received 20 or 35 injections. This alteration was observed mainly in pericentral and mid-zonal hepatocytes.

\section{Karyopyknosis}

Most hepatocytes showed shrunken nuclei with chromatin condensation that led to cell death (Figure 5D). Rats that received 35 and 50 injections of SDNPs demonstrated this alteration.

\section{Infiltration of inflammatory cells}

Infiltration of inflammatory cells was observed in all SDNPtreated rats. Focal infiltration of inflammatory cells was demonstrated in portal and lobular tissues, particularly surrounding insulted hepatocytes (Figure 5E and F).

\section{Hyperplasia of Kupffer cells}

All rats exposed to SDNPs showed activation and enlargement of Kupffer cells. This change was accompanied by widening of the capillaries lining the hepatic strands (Figure 5G).

\section{Sinusoidal dilatation}

Rats showed sinusoidal dilation (Figure 5H). This vascular alteration was characterized by widening of the capillaries

Table 2 Changes on the average body weight $(\mathrm{g})$ and the percentage of weight gain of rats subjected to different injections of SDNPs in comparison with rats received normal saline

\begin{tabular}{|c|c|c|c|c|c|c|c|c|}
\hline Dose & $\begin{array}{l}\text { Starting } \\
\text { weight }\end{array}$ & $\begin{array}{l}\text { Weight after } \\
20 \text { injections }\end{array}$ & & $\begin{array}{l}\text { Weight after } \\
35 \text { injections }\end{array}$ & & $\begin{array}{l}\text { Weight after } \\
50 \text { injections }\end{array}$ & & $p$-value \\
\hline Control rats (received & $230.8 \pm 25$ & (bw) & $(\%)$ & (bw) & $(\%)$ & (bw) & $(\%)$ & $0.027^{*}$ \\
\hline normal saline) & & $257.25 \pm 21.5$ & $1 \mathrm{I} .4 \%$ & $310 \pm 24.6$ & $34.3 \%$ & $335 \pm 17.58$ & $45 \%$ & \\
\hline Treated rats (received & $2|0.31 \pm 3|$ & (bw) & (\%) & (bw) & (\%) & (bw) & (\%) & $0.04 I^{*}$ \\
\hline $\left.\mathrm{SiO}_{2} \mathrm{NPs} ; 2 \mathrm{mg} / \mathrm{kg}\right)$ & & $235.83 \pm 29.34$ & $12.1 \%$ & $272.50 \pm 18.55$ & $29.5 \%$ & $295.17 \pm 22.93$ & $30.8 \%$ & \\
\hline
\end{tabular}

Note: *A statistically significant difference $(p$-value of $<0.05)$ using Student's ANOVA test.

Abbreviations: ANOVA, analysis of variance; NPs, nanoparticles; bw, body weight; SDNPs, silicon dioxide nanoparticles. 


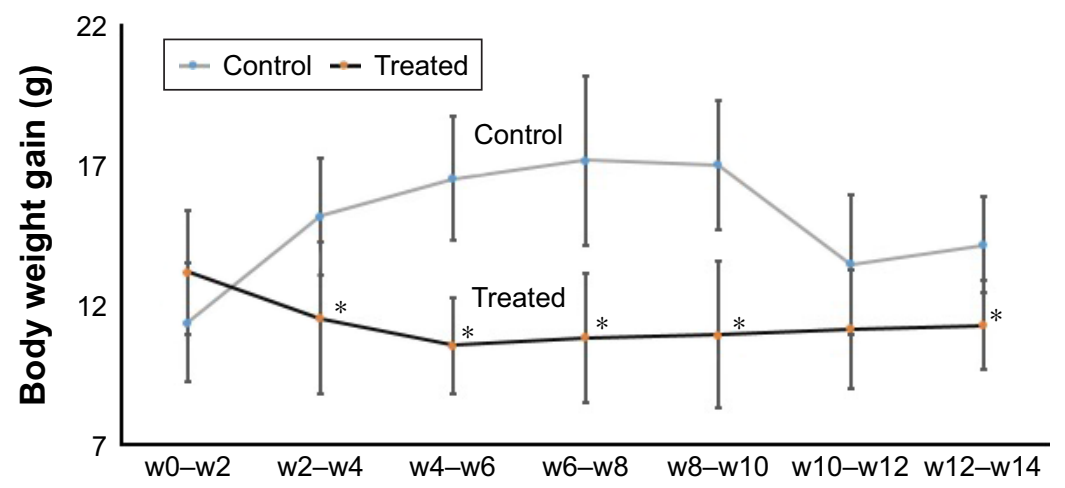

Figure I Effect of SDNPs on body weight: twice-weekly changes in body weight gain with the number of SDNP injections.

Notes: *A significant difference (Student's $t$-test, $p<0.05$ ) in comparison with the body weight gain of control rats. The decrease in the body weight gain of SDNP-treated rats in comparison with control rats is shown.

Abbreviations: SDNPs, silicon dioxide nanoparticles; w, week.

lining the hepatic strands. This change was more prominent in rats that received 50 injections of SDNPs.

\section{Gene expression}

SDNP treatment reduced the mRNA level of Phase I and Phase II drug-metabolizing enzymes and the drug transporter gene slc2a1 significantly ( $p<0.05$; Table 6$)$. The strongest reduction in gene expression was observed in cyp4a12 (31.2-fold), ephx2 (16.5-fold) and nat2 (13.3-fold).

\section{Discussion}

SDNPs are in daily use in various applications, including drug delivery, food industry, agriculture and cosmetics. This increasing use of SDNPs has raised concerns about their safety and potential risks to human health.

The morphometric findings of the current study showed a decline in body weight due to SDNP exposure. This observation might suggest oxidative stress in the pathways of metabolic enzymes and immunological status induced by SDNPs. Some researchers consider oxidative stress to be a major mechanism of the toxicity of SDNPs that may induce damage to cellular components due to the overproduction of ROS..$^{35-38}$

All control rats used in the current study demonstrated normal hematological and serum biochemical values in comparison with reference control rats. ${ }^{39}$ This result confirmed that our control rats had no toxicological or pathological indications. In the current study, rats exposed to SDNPs had increased WBC and platelet counts but lower PCT and P-LCR in comparison with the control group. Toxicologists consider increases in WBC and platelet counts to indicate oxidative stress and expression of pro-inflammatory biomarkers. ${ }^{40}$ Conversely, a significant decrease in P-LCR and PCT may indicate thrombocytosis and endothelia vascular disorders, respectively. In this regard, our findings are in agreement with those of $\mathrm{Du}$ et $\mathrm{al}^{41}$ and Chen et al, ${ }^{42}$ who found that repeated intratracheal administration of 10-nm SDNPs (dose of $30 \mathrm{mg}$ ) for 16 days and single intravenous injection of $15-\mathrm{nm}$ (dose of $50 \mathrm{mg}$ ) SDNPs increased WBC and platelet counts. However, repeated subchronic ( $\geq 28$ days) exposure of oral or dermal administration of SDNPs neither induces abnormal hematological changes nor

Table 3 Changes on the relative ratio of liver weight to body weight and the liver index of the control rats and those received 20,35 or 50 injections of SDNPs $(2 \mathrm{mg} / \mathrm{kg}$ bw)

\begin{tabular}{|c|c|c|c|c|}
\hline Dose & Average body weight (g) & $\begin{array}{l}\text { Average liver } \\
\text { weight (g) }\end{array}$ & $\begin{array}{l}\text { The percentage of } \\
\text { absolute organ weight (\%) }\end{array}$ & Liver index \\
\hline \multirow[t]{3}{*}{ Control group (normal saline) } & 20 injections $(257.25 \pm 21.5)$ & $9.82 \pm 1$ & 3.82 & I \\
\hline & 35 injections $(310 \pm 24.6)$ & 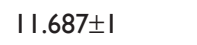 & 3.77 & \\
\hline & 50 injections (335.8 \pm 17.58$)$ & $12.35 \pm 0.9$ & 3.68 & \\
\hline $\begin{array}{l}\text { Received } \mathrm{SiO}_{2} \mathrm{NPs}(2 \mathrm{mg} / \mathrm{kg} \mathrm{bw}) \\
\text { for } 20 \text { injections }\end{array}$ & $235.83 \pm 29.34$ & $9.36 \pm 1.1$ & 3.66 & 0.96 \\
\hline $\begin{array}{l}\text { Received } \mathrm{SiO}_{2} \mathrm{NPs}(2 \mathrm{mg} / \mathrm{kg} \mathrm{bw}) \\
\text { for } 35 \text { injections }\end{array}$ & $272.50 \pm 18.55$ & $9.34 \pm 1.1$ & 3.43 & 0.91 \\
\hline $\begin{array}{l}\text { Received } \mathrm{SiO}_{2} \mathrm{NPs}(2 \mathrm{mg} / \mathrm{kg} \mathrm{bw}) \\
\text { for } 50 \text { injections }\end{array}$ & $295.17 \pm 22.93$ & $9.66 \pm 1$ & 3.27 & 0.89 \\
\hline
\end{tabular}

Abbreviations: NPs, nanoparticles; bw, body weight; SDNPs, silicon dioxide nanoparticles. 


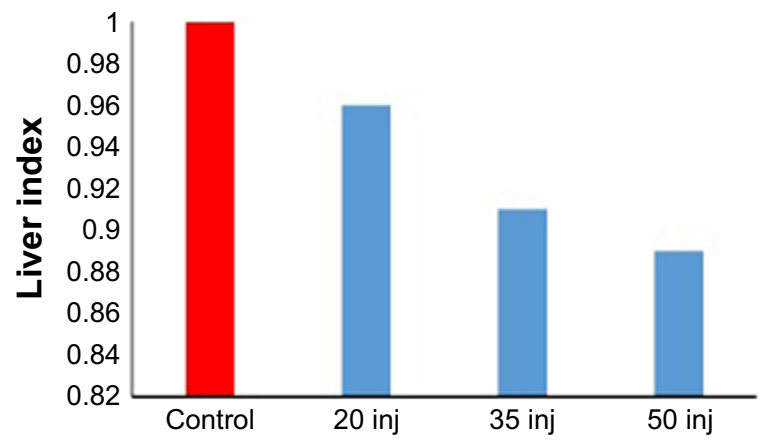

Figure 2 Change in the liver index in correlation with the number of SDNP injections. Note: The decrease in the liver index is directly proportional to the number of SDNP injections received by experimental rats.

Abbreviations: SDNPs, silicon dioxide nanoparticles; inj, injections.

induces local or systematic toxicity even at high doses. ${ }^{5,43,44}$ Overall, these data may indicate that the exposure route influences the absorption, biodistribution and toxicity of SDNPs. Most SDNPs administered via the oral route are excreted in feces and may reduce gastrointestinal absorption. ${ }^{45}$

We found that SDNP treatment increased levels of glucose, AST, ALT, alkaline phosphatase (ALP) and LDH.
Increases in glucose levels due to SDNP exposure may indicate oxidative stress induced by these nanomaterials. Increases in serum levels of ALT, AST and LDH are used as biomarkers of liver injury to detect injury and necrosis of hepatocytes. ${ }^{46,47}$ Kim et $\mathrm{al}^{48}$ showed that male Wister rats exposed to a high (333.3 mg/kg, p.o.) dose of 10-15-nm SDNPs for 5 days had increased levels of AST, ALT and ALP in serum. Conversely, Nemmar et $\mathrm{al}^{49}$ showed that injection of SDNPs $(0.25 \mathrm{mg} / \mathrm{kg}$, i.p. $)$ induced a significant increase in levels of ALT, AST and LDH along with significant DNA damage compared with saline-treated mice.

The liver is the main source of ALP, whereas LDH is concentrated in the heart, liver and RBCs. An increase in serum levels of ALP and LDH due to SDNPs as shown in the current study has been reported in studies focusing on parental injections of SDNPs. ${ }^{26,49}$ The increase in serum ALP level may indicate an abnormality in the liver, gall bladder or bone. Conversely, increases in serum levels of creatine kinase and LDH indicate damage to tissues and cells (including injury to liver tissue and muscle) and might be related to inflammation. ${ }^{50-52}$

Table 4 Serum chemistry of control rats and those received 20, 35 or 50 injections of SDNPs (2 mg/kg bw)

\begin{tabular}{|c|c|c|c|c|c|}
\hline Test & Unit & Control & $\begin{array}{l}2 \mathrm{mg} / \mathrm{kg} \\
(20 \text { injections) }\end{array}$ & $\begin{array}{l}2 \mathrm{mg} / \mathrm{kg} \\
\text { (35 injections) }\end{array}$ & $\begin{array}{l}2 \mathrm{mg} / \mathrm{kg} \\
\text { (50 injections) }\end{array}$ \\
\hline BUN & $\mathrm{mg} / \mathrm{dL}$ & $22.7 \pm 4.4$ & $21 \pm 3.5$ & $20 \pm 2.7$ & $20 \pm 3.1$ \\
\hline Glucose & $\mathrm{mg} / \mathrm{dL}$ & $142 \pm 15$ & $233 \pm 30$ & $27 I \pm 31$ & $255 \pm 27^{*}$ \\
\hline Sodium & $\mathrm{mmol} / \mathrm{L}$ & $134 \pm \mid 4$ & $132 \pm 15$ & $147 \pm 17$ & $139 \pm 15$ \\
\hline Potassium & $\mathrm{mol} / \mathrm{L}$ & $4.74 \pm 0.6$ & $6.27 \pm 0.5$ & $8.49 \pm 0.7$ & $8.85 \pm 0.7 *$ \\
\hline Calcium & $\mathrm{mg} / \mathrm{dL}$ & $10.4 \pm 1$ & $10.84 \pm 1$ & $10.92 \pm 1$ & $11.78 \pm 1.2$ \\
\hline Total bilirubin & $\mathrm{mg} / \mathrm{dL}$ & $0.05 \pm 0.005$ & $0.010 \pm 0.001$ & $0.032 \pm 0.004$ & $0.035 \pm 0.005$ \\
\hline Direct bilirubin & $\mathrm{mg} / \mathrm{dL}$ & $0.030 \pm 0.004$ & $0.026 \pm 0.004$ & $0.023 \pm 0.007$ & $0.025 \pm 0.008$ \\
\hline Amylase & IU/L & $2,529 \pm 230$ & $2,580 \pm 242$ & $2,534 \pm 276$ & $2,418 \pm 302$ \\
\hline Creatinine & $\mathrm{mg} / \mathrm{dL}$ & $0.57 \pm 0.13$ & $0.52 \pm 0.24$ & $0.55 \pm 0.17$ & $0.49 \pm 0.21$ \\
\hline CK & IU/L & $445 \pm 78$ & $456 \pm 102$ & $470 \pm 110$ & $499 \pm 78$ \\
\hline AST & IU/L & $80 \pm 12$ & $184 \pm 23$ & $170 \pm 27$ & $195 \pm 29 *$ \\
\hline ALT & IU/L & $35 \pm 2.8$ & $88 \pm 5.2$ & $85 \pm 2.7$ & $96 \pm 3.1^{*}$ \\
\hline $\mathrm{TP}$ & $\mathrm{g} / \mathrm{dL}$ & $5.85 \pm 1.13$ & $6.66 \pm 0.47$ & $6.94 \pm 0.94$ & $7.28 \pm 0.87$ \\
\hline ALB & $\mathrm{g} / \mathrm{dL}$ & $3.3 \pm 0.5$ & $3.8 \pm 0.6$ & $3.5 \pm 0.8$ & $3.8 \pm 0.7$ \\
\hline ALP & IU/L & $136 \pm 20$ & $226 \pm 27$ & $278 \pm 32$ & $29 I \pm 4 I *$ \\
\hline Cholesterol & $\mathrm{mg} / \mathrm{dL}$ & $54 \pm 7$ & $56 \pm 7$ & $63 \pm 8$ & $7 I \pm 8^{*}$ \\
\hline LDLs & $\mathrm{mg} / \mathrm{dL}$ & $20 \pm 3$ & $25 \pm 3$ & $36 \pm 3$ & $48 \pm 5^{*}$ \\
\hline HDLs & $\mathrm{mg} / \mathrm{dL}$ & $26.2 \pm 7$ & $21.5 \pm 4$ & $26.4 \pm 8$ & $22.9 \pm 9 *$ \\
\hline Triglycerides & $\mathrm{mg} / \mathrm{dL}$ & $122 \pm 22$ & $198 \pm 30$ & $181 \pm 32$ & $192 \pm 27 *$ \\
\hline Uric acid & $\mathrm{mg} / \mathrm{dL}$ & $6.79 \pm 1$ & $5.13 \pm 1.2$ & $6.28 \pm 1.3$ & $5.9 \pm 1$ \\
\hline Phosphorus & $\mathrm{mg} / \mathrm{dL}$ & $6.48 \pm 1$ & $8.04 \pm 1.3$ & $8.93 \pm 1.5$ & $11.5 \pm 2 *$ \\
\hline $\mathrm{LDH}$ & IU/L & $612 \pm 80$ & $599 \pm 76$ & $1,663 \pm 189$ & $1,170 \pm 206 *$ \\
\hline Magnesium & $\mathrm{mmol} / \mathrm{L}$ & $2.55 \pm 0.4$ & $2.42 \pm 0.5$ & $2.4 \mathrm{I} \pm 0.7$ & $2.72 \pm 0.8$ \\
\hline Iron & $\mu \mathrm{g} / \mathrm{dL}$ & $235 \pm 23$ & $233 \pm 27$ & $277 \pm 30$ & $285 \pm 32 *$ \\
\hline Chloride & $\mathrm{mmol} / \mathrm{L}$ & $103.6 \pm 14$ & $98.3 \pm 18$ & $94.7 \pm 14$ & $92.4 \pm 16$ \\
\hline
\end{tabular}

Note: *A statistically significant difference ( $p$-value of $<0.05$ ), in comparison with the $\mathrm{SiO}_{2} \mathrm{NP}$-treated groups, using ANOVA test.

Abbreviations: ALB, albumin; ALP, alkaline phosphatase; ALT, alanine aminotransferase; ANOVA, analysis of variance; AST, aspartate aminotransferase; BUN, blood urea nitrogen; CK, creatine kinase; HDLs, high-density lipids; LDH, lactate dehydrogenase; LDLs, low-density lipids; NPs, nanoparticles; TP, total protein; bw, body weight; SDNPs, silicon dioxide nanoparticles. 

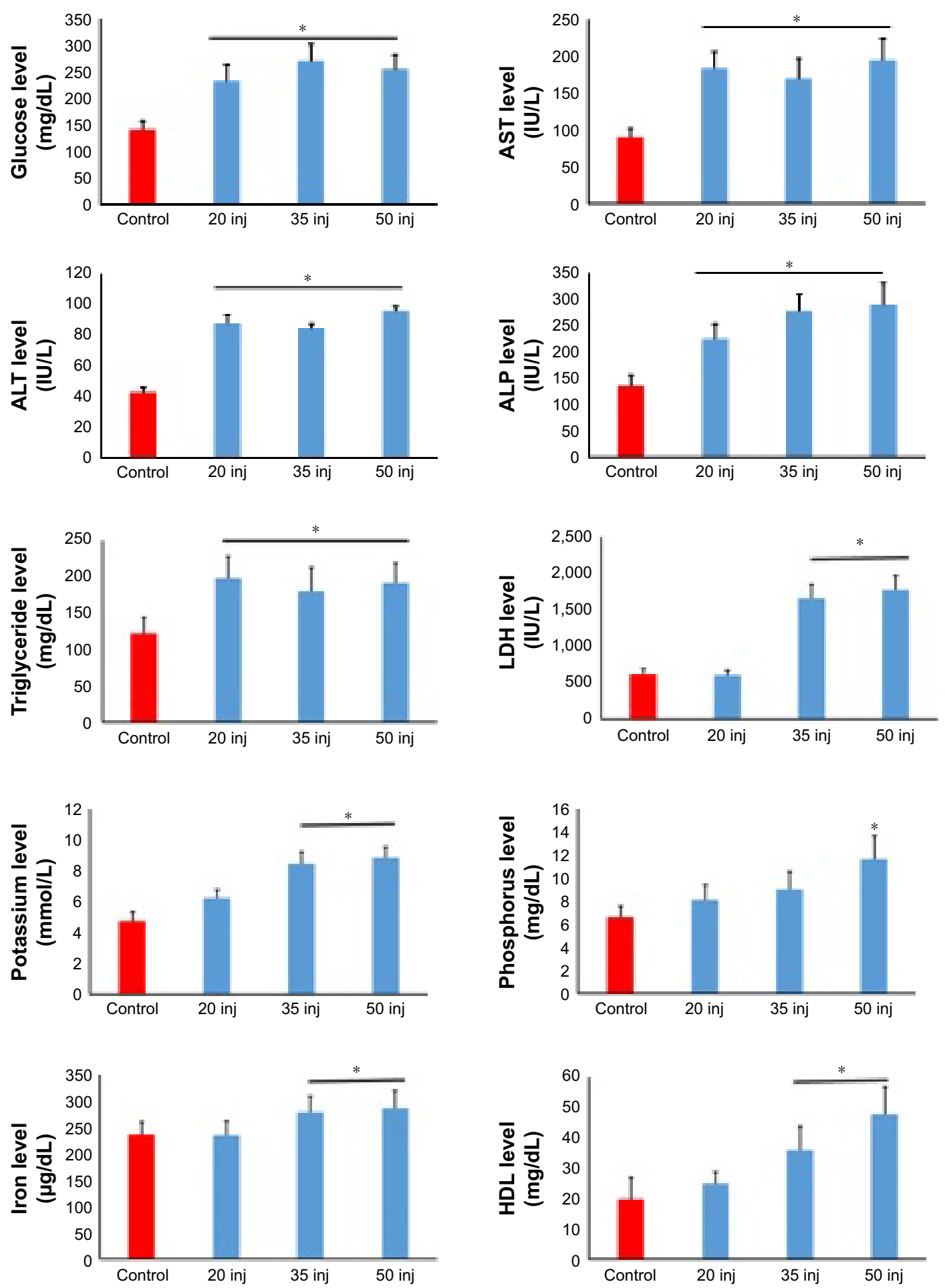

Figure 3 Analyses of biochemical alterations induced by 20, 35 and 50 injections of $10-\mathrm{nm}$ SDNPs (2 mg/kg body weight).

Note: *A significant difference ( $p$-value, Student's $t$-test) in comparison with the control group.

Abbreviations: ALP, alkaline phosphatase; ALT, alanine aminotransferase; AST, aspartate aminotransferase; HDL, high-density lipid; LDH, lactate dehydrogenase; SDNPs, silicon dioxide nanoparticles; inj, injections.

The current study showed that rats exposed to $\geq 20$ injections of SDNPs demonstrated significant increases in levels of cholesterol, low-density lipids and triglycerides. These observations are according to the findings of Hassankhani et $\mathrm{al}^{24}$ and may suggest that SDNPs can affect lipid metabolism because blood concentrations of triglycerides are often increased during hepatocellular damage..$^{53}$ The combination of increased levels of triglycerides and low-density lipids 
Table 5 Hematological analysis of control rats and those received 20, 35 or 50 injections of SDNPs (2 mg/kg bw)

\begin{tabular}{|c|c|c|c|c|c|}
\hline Test & Unit & Control & $\begin{array}{l}2 \mathrm{mg} / 20 \\
\text { injections }\end{array}$ & $\begin{array}{l}2 \mathrm{mg} / 35 \\
\text { injections }\end{array}$ & $\begin{array}{l}2 \mathrm{mg} / 50 \\
\text { injections }\end{array}$ \\
\hline WBCs & $10^{3} / \mu \mathrm{L}$ & $6.68 \pm 0.8$ & $5.54 \pm 0.7$ & $8.56 \pm 0.9$ & $9.89 \pm I^{*}$ \\
\hline $\mathrm{RBCs}$ & $10^{6} / \mu \mathrm{L}$ & $7.55 \pm 1$ & $8.23 \pm 0.8$ & $8.45 \pm 0.9$ & $7.25 \pm 1$ \\
\hline $\mathrm{Hb}$ & $\mathrm{g} / \mathrm{dL}$ & $15.3 \pm 2$ & $14.6 \pm 2$ & $13.4 \pm 2$ & $13.2 \pm 2$ \\
\hline $\mathrm{HCT}$ & $\%$ & $45.7 \pm 3.2$ & $47.4 \pm 4.1$ & $49.7 \pm 3.8$ & $46.2 \pm 3.1$ \\
\hline $\mathrm{MCV}$ & $\mathrm{fL}\left(\mu \mathrm{m}^{3}\right)$ & $57.8 \pm 3.0$ & $60.0 \pm 4.2$ & $58.5 \pm 4.2$ & $56.3 \pm 3.2$ \\
\hline $\mathrm{MCH}$ & pg & $17.5 \pm 2$ & $17.7 \pm 2$ & $16.8 \pm 2$ & $16.2 \pm 1.6$ \\
\hline $\mathrm{MCHC}$ & $\mathrm{g} / \mathrm{dL}$ & $29.1 \pm 3$ & $29.6 \pm 3.2$ & $30.8 \pm 2.7$ & $29.7 \pm 3.2$ \\
\hline Platelets & $10^{3} / \mu \mathrm{L}$ & $814 \pm 93$ & $887 \pm 83$ & $995 \pm 107$ & $986 \pm 110 *$ \\
\hline RDW-SD & $\%$ & $40.3 \pm 3.6$ & $41.8 \pm 4.2$ & $41.3 \pm 5$ & $43.6 \pm 5.7$ \\
\hline RDW-CV & $\%$ & $19.7 \pm 2.2$ & $21.1 \pm 2.5$ & $21.6 \pm 3$ & $23.5 \pm 3.2$ \\
\hline PDW & $\%$ & $10.6 \pm 1$ & $9.9 \pm 1.2$ & $10.2 \pm 1.3$ & $8.1 \pm 1$ \\
\hline MPV & $\mathrm{fL}\left(\mu \mathrm{m}^{3}\right)$ & $9.8 \pm 1.1$ & $8.2 \pm 1.2$ & $9.3 \pm 1.3$ & $7.4 \pm 1.1$ \\
\hline P-LCR & $\%$ & $21.42 \pm 3.41$ & $16.2 \pm 4.11$ & $15.7 \pm 2.84$ & $7.5 \pm 5.25 *$ \\
\hline PCT & $\%$ & $0.79 \pm 0.01$ & $0.7 I \pm 0.0 I$ & $0.66 \pm 0.01$ & $0.66 \pm 0.02 *$ \\
\hline
\end{tabular}

Note: *A significant difference $(p$-value of $<0.05)$ in comparison with the control using ANOVA test.

Abbreviations: ANOVA, analysis of variance; Hb, hemoglobin; $\mathrm{HCT}$, hematocrit; $\mathrm{MCH}$, mean corpuscular hemoglobin; MCHC, mean RBCs hemoglobin concentration; MCV, mean corpuscular volume; NPs, nanoparticles; RBCs, red blood cells; RDW-CV, relative distribution width of RBC by volume-coefficient of variation; RDW-SD, relative distribution width of RBC by volume-standard deviation; PCT, plateletcrit; PDW, platelet volume distribution width; P-LCR, platelet larger cell ratio; WBCs, white blood cells; bw, body weight; MPV, mean platelet volume; SDNPs, silicon dioxide nanoparticles.

induced by SDNP exposure may indicate a potential risk for cardiac arrest or stroke.

We also demonstrated that SDNP exposure increased the serum levels of potassium, phosphorus and iron. Hyperphosphatemia indicates the potential for diseases or infections, including hepatocytes degeneration. ${ }^{54}$ Higher-than-normal increases in serum levels of potassium may indicate disorders of the kidneys, muscles or RBCs. In addition, a high level of potassium due to SDNP exposure might be related to a hemolytic effect. This finding, along with the increase in serum levels of iron, suggests a hemolytic effect of SDNPs.

The liver plays an important part in the metabolism, detoxification and excretion of xenobiotics, including drugs and chemicals, thereby making the liver susceptible to their toxic effects. ${ }^{46}$ Some studies have suggested that the liver to be one of the target organs of SDNPs and could cause liver injury. ${ }^{20}$ Other studies have reported that the toxicity
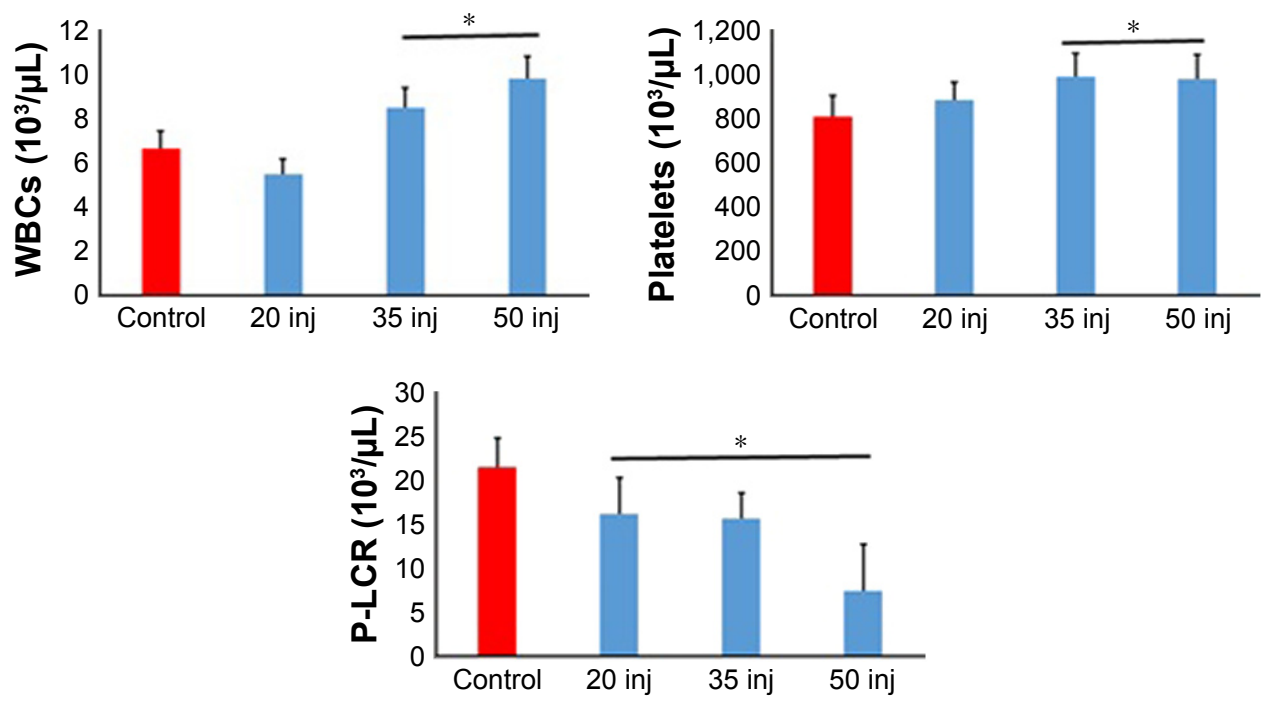

Figure 4 Analyses of hematological alterations induced by 20, 35 and 50 injections of $10-\mathrm{nm}$ SDNPs (2 mg/kg body weight).

Note: *A significant difference ( $p$-value, Student's $t$-test) in comparison with the control group.

Abbreviations: P-LCR, platelet larger cell ratio; SDNPs, silicon dioxide nanoparticles; WBCs, white blood cells; inj, injections. 

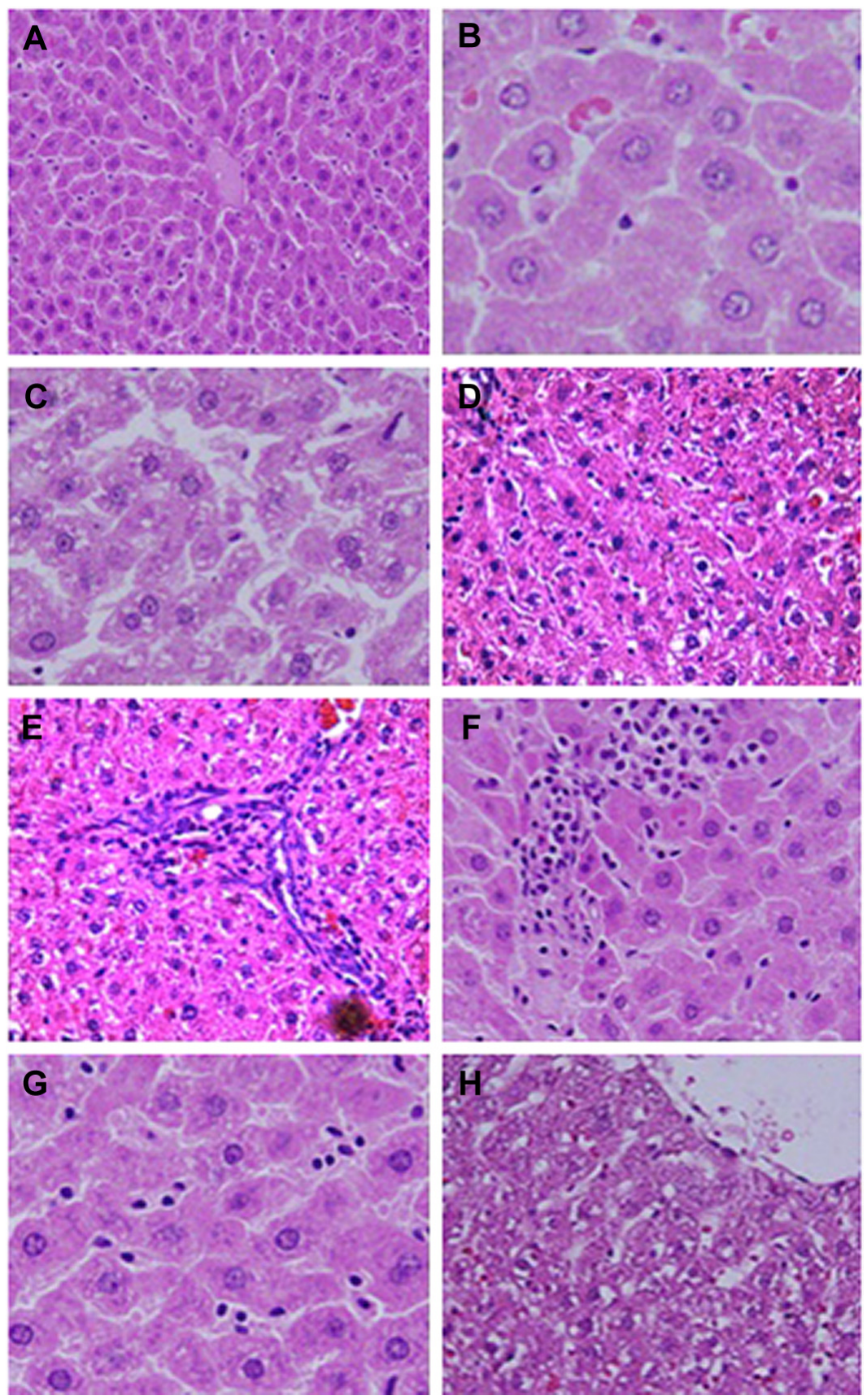

Figure 5 Microphotograph sections of the liver of control rats (A and $\mathbf{B})$ and rats subjected to 50 injections of I0-nm SDNPs $(\mathbf{C}-\mathbf{H})$, stained by H\&E.

Notes: (A) In control rats, the hepatic architecture demonstrates intact hepatic strands radiating outward from a central vein. (B) In control rats, hepatocytes display eosinophilic cytoplasm separated by vascular channels. The round nuclei dispersing smooth chromatin are shown. (C) Hydropic degeneration demonstrating swelling and cytoplasmic vacuolization. (D) Karyopyknosis showing nuclei shrinkage and chromatin condensation. (E) Infiltration of inflammatory cells demonstrating aggregation of inflammatory cells in the hepatic portal space. (F) Infiltration of lobular inflammatory cells (mainly lymphocytes) in the lobular hepatic strands. (G) Hyperplasia of Kupffer cells showing enlargement and hypertrophy of these defense cells. (H) Sinusoidal dilatation exhibiting widening of the capillaries lining the hepatic strands.

Abbreviations: H\&E, with hematoxylin and eosin; SDNPs, silicon dioxide nanoparticles.

of SDNPs is size dependent, whereby smaller SDNPs cause more hepatic injury than larger SDNPs. ${ }^{25}$ Conversely, some studies have shown that large $(150 \mathrm{~nm})$ SDNPs do not induce histological alterations in vital organs. ${ }^{55}$
The current study showed that SDNPs can induce hepatic hydropic degeneration, pyknosis, sinusoidal dilatation and Kupffer cells hyperplasia. These observations are evidence of liver damage in rats exposed to SDNPs. Some of these 
Table 6 Gene expression of drug-metabolizing enzymes in the hepatic tissues induced by SDNP exposure

\begin{tabular}{|c|c|c|c|c|}
\hline Gene & Function & $\begin{array}{l}\text { Example of } \\
\text { substrate drug }\end{array}$ & $\begin{array}{l}\text { The effect of } \mathrm{SiO}_{2} \mathrm{NPs} \\
\text { on gene expression }\end{array}$ & Fold change \pm SD \\
\hline cypla2 & Drug metabolism & Caffeine & Downregulated & $-7.3 \pm 1.05$ \\
\hline cyp2el & Drug metabolism & Nicotine & Decreased & $-6.7 \pm 1.10$ \\
\hline сур 2c29 & Drug metabolism and arachidonic acid metabolism & Warfarin & Downregulated & $-5.1 \pm 0.76$ \\
\hline сур2d9 & Drug metabolism & Morphine & Downregulated & $-7.1 \pm 0.65$ \\
\hline cyp2j5 & Drug metabolism and arachidonic acid metabolism & Amiodarone & Downregulated & $-8 \pm 0.91$ \\
\hline сур3а। I & Drug metabolism & Simvastatin & Downregulated & $-2.1 \pm 0.8$ \\
\hline сур4al 2 & Arachidonic acid metabolism & Arachidonic acid & Downregulated & $-31.2 \pm 0.95$ \\
\hline ephx2 & Arachidonic acid metabolism & Arachidonic acid & Downregulated & $-|6.5 \pm 1.5|$ \\
\hline ugt2bl & Drug metabolism & Diclofenac & Downregulated & $-6.5 \pm 0.65$ \\
\hline ugtlal & Drug metabolism & Irinotecan & Downregulated & $-5.6 \pm 0.53$ \\
\hline nat2 & Drug metabolism & Isoniazid & Downregulated & $-13.3 \pm 1.29$ \\
\hline slc22al & Transportation of drugs into the liver & Metformin & Downregulated & $-10.9 \pm 0.84$ \\
\hline
\end{tabular}

Abbreviations: NPs, nanoparticles; SDNPs, silicon dioxide nanoparticles.

findings are according to the histological alterations induced by SDNPs noted by other scholars. ${ }^{26,48}$

Hydropic degeneration is a type of cytoplasmic injury resulting from the massive influx of water into cells, which leads to the necrosis and degradation of cell organelles. Necrosis is usually seen with toxicants that affect the nucleus, endoplasmic reticulum, mitochondria and cell membrane. ${ }^{46,56}$ The resulting hepatocyte swelling and cytoplasmic vacuolation due to SDNP exposure may indicate an effect on protein synthesis by hepatocytes. In addition, the infiltration of inflammatory cells induced by SDNPs may suggest that these nanomaterials interact with hepatic interstitial tissues. Infiltration of inflammatory cells is considered to be an immune response to injury induced by ROS regeneration. ${ }^{57}$

Sinusoidal dilatation refers to widening of sinusoidal spaces resulting from the atrophy and necrosis of hepatocytes or due to injury induced by sinusoidal endothelia. The current study showed that SDNPs could induce sinusoidal dilatation and hyperplasia of Kupffer cells. These hepatohistological alterations might indicate a defense mechanism in response to the oxidative stress induced in the liver by the toxicity of SDNPs. Some studies have reported that SDNPs $(100 \mathrm{~nm})$ can induce injury to endothelial cells and cause acute liver toxicity. ${ }^{58}$

SDNPs are widely used in pharmaceutical preparations. ${ }^{59}$ The current study demonstrated that 10-nm SDNPs affected the gene expression of the drug-metabolizing enzymes such as cyp450s, ugts and nat2. These findings may indicate that silica nanomaterials could lower the capacity of the liver to metabolize drugs, which would lead to drug accumulation with the potential risk of drug toxicity. The reduced hepatic mRNA levels of drug-metabolizing enzymes might result from the toxicity induced by exposure to these nanomaterials. It has been reported that mRNA levels are lower in the livers of patients with inflammation and disorders of the liver, such as cirrhosis. ${ }^{60}$ Further intensive studies are needed to ascertain the influence of the administration of SDNPs on the pharmacokinetics and development of drug toxicity.

\section{Conclusion}

The current study suggests that exposure to SDNP results in histological alterations in the livers of rats. Significant changes in the hematological and biochemical features of the liver and gene expression of drug-metabolizing enzymes might affect the function and structure of vital organs. In addition, SDNPs may have the potential to cause oxidative stress in the body that would result in hepatocyte damage and affect liver functions. Our results elaborate the need for more studies to ascertain the toxicity induced by different sizes of SDNPs on vital organs.

\section{Acknowledgments}

The authors extend their sincere appreciation to the Deanship of Scientific Research at King Saud University for the funding of this study project (RG-1435-040). We also thank the King Abdullah II Fund for development for supporting the current study project. Moreover, providing the facilities of Jerash University at the disposal of the authors is highly appreciated. The technical help of Hanan Itriq, Yahia Abudalbouh and Dana Abusoluiman is highly appreciated.

\section{Disclosure}

The authors report no conflicts of interest in this work.

\section{References}

1. Tallury P, Payton K, Santra S. Silica-based multimodal/multifunctional nanoparticles for bioimaging and biosensing applications. Nanomedicine (Lond). 2008;3(4):579-592. 
2. Maurer-Jones M, Lin Y, Haynes C. Functional assessment of metal oxide nanoparticle toxicity in immune cells. ACS Nano. 2010;4(6):3363-3373.

3. He Q, Gao Y, Zhang L, et al. A pH-responsive mesoporous silica nanoparticles-based multi-drug delivery system for overcoming multidrug resistance. Biomaterials. 2011;32(30):7711-7720.

4. He Q, Shi J. MSN anti-cancer nanomedicines: chemotherapy enhancement, overcoming of drug resistance, and metastasis inhibition. Adv Mater. 2014;26(3):391-411.

5. Murugadoss S, Lison D, Godderis L, et al. Toxicology of silica nanoparticles: an update. Arch Toxicol. 2017;91(9):2967-3010.

6. Barik T, Sahu B, Swain V. Nanosilica-from medicine to pest control. Parasitol Res. 2008;103(2):253-258.

7. Colvin V. The potential environmental impact of engineered nanomaterials. Nat Biotechnol. 2003;21(10):1166-1170.

8. Vivero-Escoto J, Slowing I, Trewyn B, Lin V. Mesoporous silica nanoparticles for intracellular controlled drug delivery. Small. 2010;6(18): 1952-1967.

9. Benezra M, Penate-Medina O, Zanzonico P, et al. Multimodal silica nanoparticles are effective cancer-targeted probes in a model of human melanoma. J Clin Invest. 2011;121(7):2768-2780.

10. Coll C, Mondragón L, Martínez-Máñez R. Enzyme-mediated controlled release systems by anchoring peptide sequences on mesoporous silica supports. Angew Chem Int Ed. 2011;50(9):2138-2140.

11. Chu Z, Huang Y, Tao Q, Li Q. Cellular uptake, evolution, and excretion of silica nanoparticles in human cells. Nanoscale. 2011;3(8):3291-3299.

12. Liljenstrom C, Lazarevic D, Finnveden G. Silicon-Based Nanomaterials in a Life-Cycle Perspective, Including a Case Study on Self-Cleaning Coatings. Stockholm: Environmental Strategies Research KTH—Royal Institute of Technology Stockholm; 2013.

13. Vance M, Kuiken T, Vejerano E, et al. Nanotechnology in the real world: redeveloping the nanomaterial consumer products inventory. Beilstein J Nanotechnol. 2015;6:1769-1780.

14. Donaldson K, Poland CA, Schins RF. Possible genotoxic mechanisms of nanoparticles: criteria for improved test strategies. Nanotoxicology. 2010;4:414-420.

15. Zhang J, Ren L, Zou Y, et al. Silica nanoparticles induce start inhibition of meiosis and cell cycle arrest via down-regulating meiotic relevant factors. Toxicol Res. 2016;5:1453-1464.

16. Guo C, Xia Y, Niu P, et al. Silica nanoparticles induce oxidative stress, inflammation, and endothelial dysfunction in vitro via activation of the MAPK/Nrf2 pathway and nuclear factor- $\mathrm{KB}$ signaling. Int J Nanomedicine. 2015;10:1463-1477.

17. Corbalan JJ, Medina C, Jacoby A, Malinski T, Radomski MW. Amorphous silica nanoparticles trigger nitric oxide/peroxynitrite imbalance in human endothelial cells: inflammatory and cytotoxic effects. Int $J$ Nanomedicine. 2011;6:2821-2835.

18. Nemmar A, Yuvaraju P, Beegam S, et al. In vitro platelet aggregation and oxidative stress caused by amorphous silica nanoparticles. Int $J$ Physiol Pathophysiol Pharmacol. 2015;7(1):2723.

19. Ahmad J, Ahamed M, Akhtar M. Apoptosis induction by silica nanoparticles mediated through reactive oxygen species in human liver cell line HepG2. Toxicol Appl. 2012;259(2):160-168.

20. Xie G, Sun J, Zhong G, Shi L, Zhang D. Biodistribution and toxicity of intravenously administered silica nanoparticles in mice. Arch Toxicol. 2010;84(3):183-190

21. Yang YX, Song ZM, Cheng B, et al. Evaluation of the toxicity of food additive silica nanoparticles on gastrointestinal cells. $J$ Appl Toxicol. 2014;34(4):424-435.

22. Radomski A, Jurasz P, Alonso-Escolano D, et al. Nanoparticleinduced platelet aggregation and vascular thrombosis. Br J Pharmacol. 2005;146(6):882-893.

23. Chen Q, Xue Y, Sun J. Kupffer cell-mediated hepatic injury induced by silica nanoparticles in vitro and in vivo. Int J Nanomedicine. 2013;8: $1129-1140$.

24. Hassankhani R, Esmaeillou M, Tehrani A, Nasirzadeh K, Khadir F, Maadi $\mathrm{H}$. In vivo toxicity of orally administrated silicon dioxide nanoparticles in healthy adult mice. Environ Sci Pollut Res Int. 2015;22(2): $1127-1132$.
25. Isoda K, Tetsuka E, Shimizu Y, Saitoh K, Ishida I, Tezuka M. Liver injury induced by thirty- and fifty-nanometer-diameter silica nanoparticles. Biol Pharm Bull. 2013;36(3):370-375.

26. Limbach L, Wick P, Manser P, Grass R, Bruinink A, Stark W. Exposure of engineered nanoparticles to human lung epithelial cells: influence of chemical composition and catalytic activity on oxidative stress. Environ Sci Technol. 2007;41(11):4158-4163.

27. Kaewamatawong T, Kawamura N, Okajima M, Sawada M, Morita T, Shimada A. Acute pulmonary toxicity caused by exposure to colloidal silica: particle size dependent pathological changes in mice. Toxicol Pathol. 2005;33(7):743-749.

28. Kaewamatawong T, Shimada A, Okajima M, et al. Acute and subacute pulmonary toxicity of low dose of ultrafine colloidal silica particles in mice after intratracheal instillation. Toxicol Pathol. 2006;34(7): 958-965.

29. McCarthy J, Inkielewicz-Stępniak I, Corbalan JJ, Radomski M. Mechanisms of toxicity of amorphous silica nanoparticles on human lung submucosal cells in vitro: protective effects of fisetin. Chem Res Toxicol. 2012;25(10):2227-2235.

30. Akhtar M, Ahamed M, Kumar S, et al. Nanotoxicity of pure silica mediated through oxidant generation rather than glutathione depletion in human lung epithelial cells. Toxicology. 2010;276(2):95-102.

31. Napierska D, Thomassen LC, Lison D, Martens JA, Hoet PH. The nanosilica hazard: another variable entity. Part Fibre Toxicol. 2010; $7(1): 39$.

32. Wang JJ, Sanderson BJ, Wang H. Cytotoxicity and genotoxicity of ultrafine crystalline $\mathrm{SiO}_{2}$ particulate in cultured human lymphoblastoid cells. Environ Mol Mutagen. 2007;48(2):151-157.

33. Stern S, Adiseshaiah P, Crist R. Autophagy and lysosomal dysfunction as emerging mechanisms of nanomaterial toxicity. Part Fibre Toxicol. 2012;9:20.

34. Livak KJ, Schmittgen TD. Analysis of relative gene expression data using real-time quantitative PCR and the 2(-Delta $\mathrm{C}(\mathrm{T})$ ) method. Methods. 2001;25(4):402-408.

35. Wang F, Gao F, Lan M, Yuan H, Huang Y, Liu J. Oxidative stress contributes to silica nanoparticle-induced cytotoxicity in human embryonic kidney cells. Toxicol In Vitro. 2009;23(5):808-815.

36. Ye Y, Liu J, Chen M, Sun L, Lan M. In vitro toxicity of silica nanoparticles in myocardial cells. Environ Toxicol Pharmacol. 2010;29(2): 131-137.

37. Ye Y, Liu J, Xu J, Sun L, Chen M, Lan M. Nano-SiO ${ }_{2}$ induces apoptosis via activation of $\mathrm{p} 53$ and Bax mediated by oxidative stress in human hepatic cell line. Toxicol In Vitro. 2010;24(3):751-758.

38. Fu P, Xia Q, Hwang H, Ray P, Yu H. Mechanisms of nanotoxicity: generation of reactive oxygen species. J Food Drug Anal. 2014;22(1): 64-75.

39. Ginkis M, Clifford C. Clinical Laboratory Parameters for Crl; WI (Han) Rats. Quebec: Charles River Laboratories, Montreal Inc; 2008.

40. Thomsen M, Ingebrigtsen T, Marott JL, et al. Inflammatory biomarkers and exacerbations in chronic obstructive pulmonary disease. JAMA. 2013;309(22):2353-2361.

41. Du Z, Zhao D, Jing L, et al. Cardiovascular toxicity of different sizes amorphous silica nanoparticles in rats after intratracheal instillation. Cardiovasc Toxicol. 2013;13(3):194-207.

42. Chen Q, Xue Y, Sun J. Kupffer cell-mediated hepatic injury induced by silica nanoparticles in vitro and in vivo. Int J Nanomedicine. 2013;8: 1129-1140.

43. Ryu H, Seong N, So B, et al. Evaluation of silica nanoparticle toxicity after topical exposure for 90 days. Int J Nanomedicine. 2014;9(Suppl 2): $127-136$.

44. Yun J, Kim S, You J, et al. Comparative toxicity of silicon dioxide, silver and iron oxide nanoparticles after repeated oral administration to rats. $J$ Appl Toxicol. 2015;35(6):681-693.

45. Lee JA, Kim MK, Paek HJ, et al. Tissue distribution and excretion kinetics of orally administered silica nanoparticles in rats. Int $J$ Nanomedicine. 2014;9(Suppl 2):251-260.

46. Singh A, Bhatm T, Sharma O. Clinical biochemistry and hepatotoxicity. J Clin Toxicol. 2011;4:1-19. 
47. Yu Y, Li Y, Wang W, et al. Acute toxicity of amorphous silica nanoparticles in intravenously exposed ICR mice. PLoS One. 2013; 8(4):e61346.

48. Kim I, Joachim E, Choi H, Kim K. Toxicity of silica nanoparticles depends on size, dose and cell type. Nanomedicine. 2015;11(6):1407-1416.

49. Nemmar A, Yuvaraju P, Beegam S, Yasin J, Kazzam E, Ali B. Oxidative stress, inflammation, and DNA damage in multiple organs of mice acutely exposed to amorphous silica nanoparticles. Int J Nanomedicine. 2016;11:919-928.

50. Brancaccio P, Lippi G, Maffulli N. Biochemical markers of muscular damage. Clin Chem Lab Med. 2010;48:757-767.

51. Elsayed E, Reilly R. Rhabdomyolysis: a review, with emphasis on the pediatric population. Pediatr Nephrol. 2010;25(1):7-18.

52. Chavez L, Leon M, Einav S, Varon J. Beyond muscle destruction: a systematic review of rhabdomyolysis for clinical practice. Crit Care. 2016; 20(1): 135

53. Liu J, Han L, Zhu L, Yu Y. Free fatty acids, not triglycerides, are associated with non-alcoholic liver injury progression in high fat diet induced obese rats. Lipids Health Dis. 2016;15:27.

54. Chung P, Sitrin M, Te S. Serum phosphorus levels predict clinical outcome in fulminant hepatic failure. Liver Transpl. 2003;9(3):248-253.
55. Chan W, Liu C, Chiang J, et al. In vivo toxicologic study of larger silica nanoparticles in mice. Int J Nanomedicine. 2017;12:3421-3432.

56. George S, Pokhrel S, Xia T, et al. Use of a rapid cytotoxicity screening approach to engineer safer zinc oxide nanoparticles through iron doping. ACS Nano. 2010;4(1):15-29.

57. Johar D, Roth J, Bay G, Walker J, Kroczak T, Los M. Inflammatory response, reactive oxygen species, programmed (necrotic-like and apoptotic) cell death and cancer. Rocz Akad Med Bialymst. 2004;49: 31-39.

58. Hasezaki T, Isoda K, Kondoh M, Tsutsumi Y, Yagi K. Hepatotoxicity of silica nanoparticles with a diameter of $100 \mathrm{~nm}$. Pharmazie. 2011;66(9): 698-703.

59. Tang H, Xiang D, Wang F, Mao J, Tan X, Wang Y. 5-ASA-loaded $\mathrm{SiO}_{2}$ nanoparticles - a novel drug delivery system targeting therapy on ulcerative colitis in mice. Mol Med Rep. 2017;15(3):1117-1122.

60. Congiu M, Mashford ML, Slavin JL, Desmond PV. UDP glucuronosyltransferase mRNA levels in human liver disease. Drug Metab Dispos. 2002;30(2):129-134.
International Journal of Nanomedicine

\section{Publish your work in this journal}

The International Journal of Nanomedicine is an international, peerreviewed journal focusing on the application of nanotechnology in diagnostics, therapeutics, and drug delivery systems throughout the biomedical field. This journal is indexed on PubMed Central, MedLine, CAS, SciSearch ${ }^{\circledR}$, Current Contents ${ }^{\circledR} /$ Clinical Medicine,

\section{Dovepress}

Journal Citation Reports/Science Edition, EMBase, Scopus and the Elsevier Bibliographic databases. The manuscript management system is completely online and includes a very quick and fair peer-review system, which is all easy to use. Visit http://www.dovepress.com/ testimonials.php to read real quotes from published authors. 